\title{
Variability and recent trends in the African terrestrial carbon balance
}

\author{
P. Ciais ${ }^{1}$, S.-L. Piao ${ }^{2}$, P. Cadule ${ }^{1}$, P. Friedlingstein ${ }^{1}$, and A. Chédin ${ }^{3}$ \\ ${ }^{1}$ LSCE, UMR CEA-CNRS, Bat. 709, CE, L'Orme des Merisiers, 91191 Gif-sur-Yvette, France \\ ${ }^{2}$ Department of Ecology, College of Urban and Environmental Sciences, Peking University, Beijing 100871, China \\ ${ }^{3}$ Groupe Analyse du Rayonnement Atmospherique, Laboratoire de Meteorologie Dynamique, Institut Pierre Simon Laplace, \\ ARA/LMD/IPSL, Ecole Polytechnique RD 36, 91128 Palaiseau Cedex, France
}

Received: 8 July 2008 - Published in Biogeosciences Discuss.: 2 September 2008

Revised: 28 August 2009 - Accepted: 28 August 2009 - Published: 29 September 2009

\begin{abstract}
We modeled the African terrestrial carbon balance over the past century using a spatially resolved process based vegetation model (ORCHIDEE). The model is forced by changing climate and by human-induced changes in land use. It includes a simple parameterization of natural fires, but the natural vegetation dynamics was ignored. The period analyzed is 1901-2002. Overall, we found that the African net terrestrial carbon balance (Net Biome Productivity, NBP) increased from a net $\mathrm{CO}_{2}$ source to the atmosphere of $0.14 \mathrm{Pg} \mathrm{C} \mathrm{yr}^{-1}$ in the 1980 s to a net sink of $0.15 \mathrm{Pg} \mathrm{C} \mathrm{yr}^{-1}$ in the 1990s. The land use flux alone is estimated to be a source of $0.13 \mathrm{PgC} \mathrm{yr}^{-1}$ caused by deforestation. This implies that climatic trends (mainly increasing precipitation) and $\mathrm{CO}_{2}$ increase (fertilization effect), are causing a sink of $0.28 \mathrm{Pg} \mathrm{Cyr}^{-1}$ which offsets the land-use source. We found that the interannual variability of NBP is large, and mostly driven by photosynthesis variability. Over savannas, photosynthesis changes from one year to the next are strongly correlated with rainfall changes $\left(R^{2}=0.77\right.$ in northern Africa, and $R^{2}=0.42$ in southern African savannas). Over forests, such a control by rainfall is not found. The main spatial pattern of interannual variability in NBP and photosynthesis/ecosystem respiration fluxes is related with ENSO, with dryer conditions prevailing over savannas during El Niño and wetter conditions over forests. Climate induced variations in fire emissions respond to this ENSO forcing, but do not determine strongly the NBP interannual variability. Finally, we model that ecosystem respiration variations (mostly autotrophic respiration) are correlated with those of photosyn-
\end{abstract}

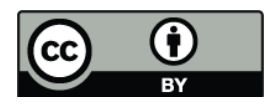

Correspondence to: P. Ciais (philippe.ciais@1sce.ipsl.fr) thesis, on interannual as well as on decadal time scales, but this result is uncertain given the potential for acclimation for autotrophic respiration processes.

\section{Introduction}

Little is known about the carbon balance of the African continent. One particularity of Africa is the extensive presence of savannas, with $15.1 \times 10^{6} \mathrm{~km}^{2}$, roughly $50 \%$ of the continent (Menaut et al., 1985) and 70\% of the World's savannas. Savannas is a productive vegetation (Lieth and Wietaker, 1975; Scholes and Hall, 1996) as compared to other biomes, with an average Net Primary Productivity (NPP) of $720 \pm 200 \mathrm{gC} \mathrm{m}^{-2} \mathrm{yr}^{-1}$ (Grace et al., 2006). Scaling up this estimate to the entire African savanna biome gives an NPP of $8.9 \mathrm{Pg} \mathrm{C} \mathrm{yr}^{-1}$, that is $13.6 \%$ of the global NPP. Apart from savanna, forest is also an important biome in Africa. African forests are among the most pristine on Earth and contain large carbon stocks in biomass, up to $400 \mathrm{tC} \mathrm{ha}^{-1}$ in Equatorial rainforests (Brown et al., 1996). These forest carbon stocks are vulnerable to human impact and to climate change.

In Africa, the population is increasing faster than in other regions of the globe (source: http://maps.grida.no/ go/graphic/population_and_development_in_africa). Further, more than $40 \%$ of the population lives in arid, semi arid or dry sub-humid areas, increasing the pressure on ecosystem services, in particular for agricultural production (Sultan et al., 2005; Ingram et al., 2002; De Rouw, 2004). Currently, the human appropriation of NPP in populated regions of Africa is as high as in Europe, although actual NPP is $\approx 15 \%$ than natural vegetation NPP (Haberl et al., 2007).

Published by Copernicus Publications on behalf of the European Geosciences Union. 
Therefore, it is important to quantify the mean productivity of natural ecosystems, as well as its variability and trends, as the NPP of cultivated ecosystems is most likely lower than natural NPP in this region (Haberl et al., 2007). West Africa, the most densely populated region of the continent, is subject to strong interannual and decadal precipitation changes. There is a drought trend in this region since 1950, followed by a reversal to wetter conditions after 1980 but rainfall has not yet reached back the 1950 levels. The recent drought strucked the region at the end of the 1960's till the beginning of the 1990's. The recent years (1994-2006) are characterized by still dry conditions in the Western Sahel while the Eastern Sahel benefits from wetter conditions (Ali and Lebel, 2009). Further, changes in global and local economic drivers, in population density and wealth are likely to modify regionally the regime of fires, which in turn will change the productivity and the carbon balance of savannas and forests.

A second important motivation for studying the carbon balance of Africa is that deforestation in Central Africa, has been historically less pronounced than in other tropical continents (Houghton et al., 2003), but is now catching up. Although their exploitation is partly regulated, Central African forests are under the threat of accelerated logging, with $30 \%$ of these forests being under logging concessions (Laporte et al., 2007). The wood removal from African forest increased from $500 \times 10^{6} \mathrm{~m}^{3}$ (roughly $0.125 \mathrm{Pg} \mathrm{C} \mathrm{yr}^{-1}$ ) to $660 \times 10^{6} \mathrm{~m}^{3}$ in 2005 (FAO, 2007). Recently, the area of forest and other woodlands in Africa decreased between 2000 and 2005 at a high rate of $6 \times 10^{6}$ ha per year, explaining more than half of the global decline in forest area (FAO, 2007). The African forest carbon stocks thus appear to be particularly vulnerable, although they have been spared from massive deforestation so far (Canadell et al., 2009). In the context of the Reduced Emission in Deforestation from Developing countries (REDD) program, it is thus important to quantify both the carbon stocks and the carbon fluxes of African forests, since these stocks may be larger and less affected by clearing than in other regions of the Tropics.

Unfortunately, in situ data are scarce and incomplete to characterize the African carbon balance. Apart from forest inventories in few countries (FAO, 2007), some ecosystem scale measurements (e.g. Abbadie et al., 2006) or regional campaigns like the SAFARI-2000 programme, the IGBP African transects initiated 10-years ago (Koch et al., 1995) have not delivered comprehensive information on carbon stocks and fluxes. In that context, remote sensing data and ecosystem models form the base of our knowledge to tackle the problem of quantifying and understanding the African carbon balance and drivers (e.g. Hiernaux et al., 2008).

In this paper, we use the ORCHIDEE (ORganizing Carbon and Hydrology in Dynamic EcosystEms; Krinner et al., 2005) process-based global vegetation model to simulate the carbon balance of the African continent, and its component fluxes of photosynthesis, respiration and fire emissions. The period of study is the past century, allowing to analyze in- terannual variability, and to gain further insights on decadal variability. After a description of the modeling framework (Sect. 2), we analyze the impacts of climate variability on carbon fluxes (Sect. 3). The associated continental-scale and regional modes of variability are discussed. Since the ORCHIDEE model also participated to the CAMIC (CarboAfrica Model Inter Comparison) experiment, which covers the past 25 years (Weber et al., 2009), we will give more focus here in the discussion of interannual variability during the past century. Then, the effects of long-term climate trends, rising $\mathrm{CO}_{2}$, and changes in land use are studied (Sect. 4). In that context, the results of ORCHIDEE are evaluated against long-term satellite observation of vegetation greenness and against river runoff observations.

The goal of this preliminary work is not to provide a realistic quantitative assessment of the African carbon balance and its drivers. Neither at this early stage of the CARBOAFRICA project, nor through past projects, we have enough data to falsify or confirm the model predictions. Rather, we seek to gain a deeper understanding of our model's behavior over Africa, attempting wherever this is possible to check and understand the arising model output against global datasets.

\section{Methods}

\subsection{Model structure}

The ORCHIDEE model (Krinner et al., 2005) is a dynamic global vegetation model representing key vegetation processes governing biogeochemistry, soil hydrology, and biogeography. The ORCHIDEE model includes three coupled submodels: a surface-vegetation-atmosphere transfer model SECHIBA (Ducoudré et al., 1993), a carbon dynamics model called STOMATE, and a vegetation dynamics model inspired from LPJ (dealing with fire, sapling establishment, light competition, and tree mortality). This later sub-model is nonactivated (except for fires) because we will prescribe vegetation changes. SECHIBA calculates the transfer of radiation, water and heat in the vegetation-soil-atmosphere system at half hourly time step. ORCHIDEE distinguishes over Africa 11 plant functional types with different photosynthetic, phenological and morphological characteristics. Root water uptake $(U)$ in ORCHIDEE is function of the biome-dependent constant $c$ and of the dry soil depth $d$, defined as the dry fraction of the first soil moisture layer $\left(U=e^{-c d}\right.$, where $U$ varies between 0 and $1, c=0.8$ for forest and $c=4$ for grassland). The STOMATE submodel simulates plant phenology and key processes of ecosystem carbon cycling such as gross primary productivity (GPP), growth and maintenance respiration, NPP allocation, and litter and soil organic matter decomposition. Plant $\mathrm{CO}_{2}$ assimilation interacts with stomatal conductance and is regulated by environmental factors such as air humidity, temperature, radiation, and atmospheric $\mathrm{CO}_{2}$ concentration. Photosynthesis in ORCHIDEE is based on the 
leaf model equations of Farquhar et al. (1980) for C3 plants and of Collatz et al. (1992) for C4 plants (savannas). Maintenance respiration is a function of each living biomass pool and temperature. Growth respiration is computed as a fraction of the difference between assimilation inputs and maintenance respiration outputs to plant biomass. Heterotrophic respiration parameterization is taken from the CENTURY model (Parton et al., 1988). ORCHIDEE has altogether eight litter pools and six soil carbon pools.

In ORCHIDEE, fire is one of the main disturbance affecting the terrestrial vegetation. A simple parameterization following McNaughton et al. (1989) is included in ORCHIDEE. The formulation of fire occurrence follows an intermediate approach between the fire history concept (using statistical relationships between the length of the fire season and the area burnt) and a process-oriented methodology (estimation of fire conditions based on litter quantity and moisture) such as for instance in Thonicke et al. (2001). Land use change is another major disturbance that can greatly modify terrestrial carbon storage and flux. The fractions of each land use type (PFT) are updated annually. After a transition in land use, a fraction of the aboveground heartwood and sapwood carbon pools is transferred to three product pools with different turnover times. The carbon contained in other biomass pools which remain in the ecosystem is added to the litter reservoir, and eventually released to the atmosphere by decomposition. For tropical forest, fractions of 59.7\%, 40.3\%, and $0 \%$ of the harvested heartwood and sapwood aboveground biomass are assigned to product decay pools with $1 \mathrm{yr}, 10 \mathrm{yr}$ and $100 \mathrm{yr}$ turnover time (Mc Guire et al., 2001). For temperate forest biome (only $12 \%$ of African forest) these fractions are $59.7 \%, 29.9 \%$, and $10.4 \%$. Carbon in these pools decays outside from ecosystems and outside of Africa if wood is exported.

ORCHIDEE was validated against observed seasonal cycles of heat, $\mathrm{CO}_{2}$ and $\mathrm{H}_{2} \mathrm{O}$ exchanges at various Fluxnet sites around the world (Krinner et al., 2005; Ciais et al., 2005; Chevallier et al., 2006) but not specifically at savanna sites. It was evaluated as well as with the satellite derived spatial distribution of vegetation traits and leaf density at global or regional scales (Krinner et al., 2005; Demarty et al., 2007). The interannual variability in leaf area index (LAI), carbon fluxes, and runoff is also consistent with that of historical satelliteobserved LAI, seasonal cycle of atmospheric $\mathrm{CO}_{2}$, and observed runoff, respectively (Piao et al., 2006, 2007, 2008). In the recent Dynamic Global Vegetation Model (DGVM) comparison of Sitch et al. (2008), the ORCHIDEE simulated response of net carbon exchange to future climate and rising $\mathrm{CO}_{2}$ concentration was found to be intermediate among the five participating DGVM, the other models being S-DGVM, HYBRID, TRIFFID and LPJ.

\subsection{Input datasets}

\subsubsection{Climate data}

The meteorological data used to drive ORCHIDEE include air temperature, precipitation, wet day frequency, diurnal temperature range, cloud cover, relative humidity of the air and wind speed. Monthly data sets, with a spatial resolution of $0.5^{\circ} \times 0.5^{\circ}$ for $1901-2002$, were supplied by the Climatic Research Unit (CRU), School of Environmental Sciences, University of East Anglia, UK (Mitchell and Jones, 2005). Data on annual atmospheric $\mathrm{CO}_{2}$ concentration were obtained from Rayner et al. (2005). The current soil texture map is based on Zobler (1986).

\subsubsection{Land use data}

Cropland area is prescribed each year from the dataset of Ramankutty and Foley (1999). We have combined this dataset with that of Goldewijk (2001) to account for the extent of pasture. The distribution of natural vegetation at each grid cell is derived from Loveland et al. (2000). The extent of natural vegetation varies with time as a function of the prescribed extent of cropland and pasture. The evolution of area for each type of African vegetation is shown in Fig. 6c.

\subsection{Simulations setup}

Using transient climate data during the period 1901-1910 and the 1860 atmospheric $\mathrm{CO}_{2}$ concentration of $286.05 \mathrm{ppm}$, we first ran the model at resolution of $2^{\circ} \times 2^{\circ}$ until the carbon pools reach equilibrium (spin-up of $10000 \mathrm{yrs}$ ). Within a $2^{\circ}$ grid cell, different vegetation types co-exist and each will have a different equilibrium pool value. From this initial equilibrium state, two simulations from 1860 to 2002 were carried out, in order to separate the relative contribution of atmospheric $\mathrm{CO}_{2}$, climate change, and of land use change. In simulation $\mathrm{S} 1$, atmospheric $\mathrm{CO}_{2}$ and climate were varied. In simulation $\mathrm{S} 2$, atmospheric $\mathrm{CO}_{2}$ concentration, climate and land use were varied. The individual effects of land use change were estimated by subtracting S1 from S2. Due to lack of climate data before 1901, the average climate data during the period of 1901-1910 was used for the 1860-1900 initialization.

In addition, we performed three shorter simulations over the period 1980-2002, to isolate the effects of temperature and precipitation alone, and the role of $\mathrm{CO}_{2}$. We checked that our climate forcing dataset during that period is quite similar to the dataset based upon CRU climate combined with NCEP analysis and TRMM satellite rainfall prepared by Weber et al. (2009) for the CAMIC model intercomparison. In this way, our attribution of flux variations to rising $\mathrm{CO}_{2}$ vs. climate drivers could be extrapolated to the ORCHIDEE results part of the CAMIC intercomparison. To perform the attribution of fluxes to each driving variable, we carried a simulation $\mathrm{S} 3$ in which only $\mathrm{CO}_{2}$ is varied, a simulation $\mathrm{S} 4$ 
Table 1. Description of simulations used in this study.

\begin{tabular}{|c|c|c|}
\hline Simulation & Period & Factors \\
\hline S1 & 1901-2002 & Climate+atmospheric $\mathrm{CO}_{2}$ \\
\hline S2 & 1901-2002 & $\begin{array}{l}\text { Climate+atmospheric } \mathrm{CO}_{2} \\
+ \text { land use change }\end{array}$ \\
\hline S3 & 1980-2002 & atmospheric $\mathrm{CO}_{2}$ \\
\hline S4 & 1980-2002 & precipitation \\
\hline S5 & 1980-2002 & temperature \\
\hline
\end{tabular}

in which precipitation alone is varied, and a simulation S5 in which temperature alone is varied.

The definition and abbreviations used in this paper for the different carbon fluxes (gross primary production, GPP, net primary production, NPP, heterotrophic respiration, TER, total ecosystem respiration, $\mathrm{RH}$, autotrophic respiration RA, LUC the net land use change flux) are the same as Krinner et al. (2005). The long-term terrestrial carbon balance or Net Biome Productivity (NBP) is defined by NBP $=$ GPP - TER - fire - LUC. The time period considered for mean fluxes is the last decade of the simulation 19901999 unless otherwise specified.

\section{Interannual variability}

In this section, we analyze C flux interannual variations. Since 1981, the wettest year over the African continent is 1994, and the driest years are 1970 and 1981, with a series of severe droughts in the Sahel during 1983-1984. Over the past century, extreme wet years occurred in 1909, 1940, 1961-1963. The dryest years are 1913, 1919, 1950 and poor rainfalls are observed in Sahel during the 1970's. Every dry year is correlated with an abnormal source of $\mathrm{CO}_{2}$ to the atmosphere, correlated with a drop in GPP and a drop in TER. An opposite response is found to wet years. We do not discuss in details $\mathrm{C}$ flux variations during the earlier part of the past century, because of uncertainties in climate drivers. The authors of the CRU climate data state that for temperature : "Annual values are approximately accurate to $\pm 0.05^{\circ} \mathrm{C}$ (two standard errors) for the period since 1951. They are about four times as uncertain during the 1850s, with the accuracy improving gradually between 1860 and 1950 except for temporary deteriorations during data-sparse, wartime intervals" and that "Fluctuations over time in the numbers and locations of adjacent stations may lead to abrupt and incorrect changes in the climate of an individual grid box, particularly changes in variability" (Mitchell et al., 2004). In the following, we analyze the results of simulation S1.

Five main results emerge from our analysis. First, the interannual variability in the Net Biome Productivity (NBP) is of smaller magnitude than the variability of each gross

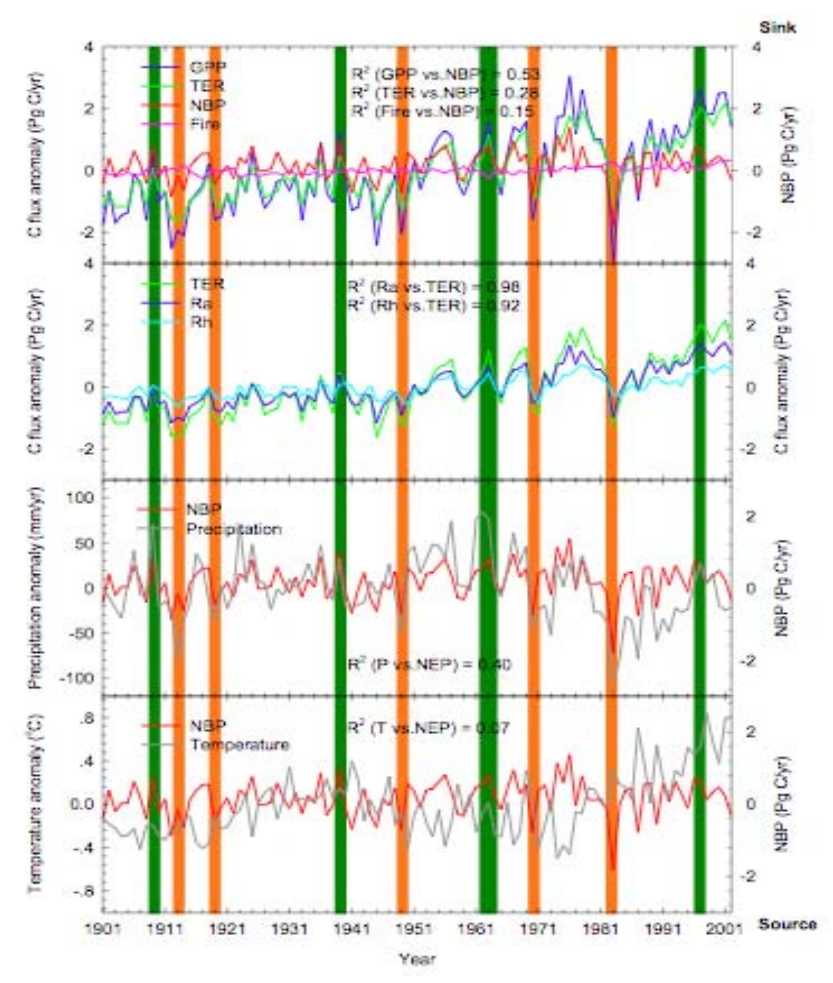

Fig. 1. Interannual changes in anomalies of total GPP, TER, Fire emission, NBP, Ra, Rh, annual precipitation, and annual mean temperature from 1901 to 2002 . Positive values of NBP indicate carbon sink and negative values of NBP indicate carbon source. Orange vertical bars indicate the dryest years, and dark green bars the wettest years.

flux separates, suggesting a strong coupling causing a positive correlation between Total Ecosystem Respiration (TER) and Gross Primary Productivity (GPP) in the model (Fig. 1). This result, valid over the entire African continent, is similar to the one obtained by Ciais et al. (2005) in their analysis of the summer 2003 drought in Europe. Further, our simulations suggest that TER variations are smaller than GPP variations, although in phase with them. In other words, the GPP anomalies are systematically correlated with TER anomalies of the same sign (Fig. 2). In the model, each strong drought such as 1913, 1984 (the last extreme drought in Western Africa), and 1987 causes a drop in GPP (Fig. 1) and in the subsequent allocation of assimilates to leaves and roots, which limits the production of litter for respiration. In addition, during these droughts, the decomposition of soil organic matter is further reduced by soil dryness. However, the drought induced GPP reductions are always larger in ORCHIDEE than the coincident TER reductions (Fig. 2). In response to extreme drought years (Fig. 2) defined when continental scale precipitation drops by more than $5 \%$ below the 9 -year average centered over that year, autotrophic respiration (RA) is decreased by $16 \mathrm{gC} \mathrm{m}^{-2} \mathrm{yr}^{-1}$, more than twice the heterotrophic respiration $(\mathrm{RH})$ decrease 


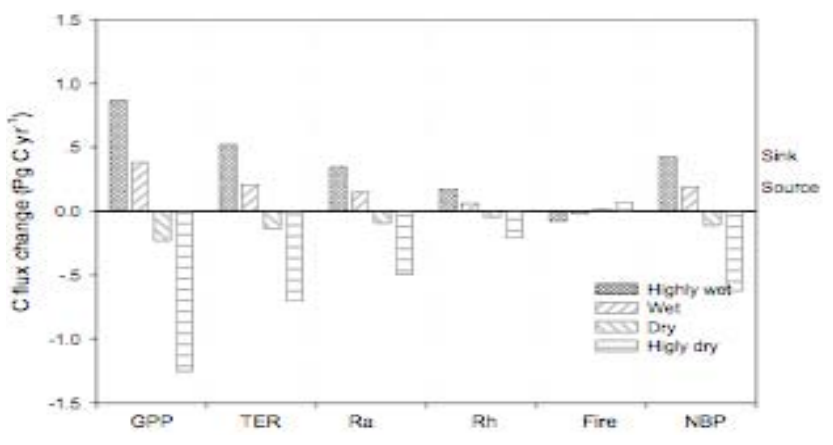

Fig. 2. The average response of GPP, TER, Ra, Rh, carbon emission driven by fire, and NBP in Africa to the change precipitation. Highly wet year is the year when precipitation is higher than $5 \%$ of the 9-year means over the period surrounding each event by \pm 4 years; wet year is the year when precipitation is higher than $0-5 \%$ of the 9-year means over the period surrounding each event by \pm 4 years; dry year is the year when precipitation is les than $0-5 \%$ of the 9 -year means over the period surrounding each event by \pm 4 years; and highly dry year is the year when precipitation is less than $5 \%$ of the 9-year means over the period surrounding each event by \pm 4 years.

of $7 \mathrm{gC} \mathrm{m}^{-2} \mathrm{yr}^{-1}$. The converse is true for extremely wet years. This shows that, in the ORCHIDEE model, the variations in TER consecutive to those of GPP are two-third explained by changes in the modeled autotrophic respiration and one third explained by heterotrophic respiration processes.

Second, the interannual variability in the Net Biome Productivity $(N B P)$ is driven by the interanuality of GPP rather than by the one of TER (Fig. 3). This feature of the ORCHIDEE model is rather widespread and has been diagnosed in global simulations to extend from the southern half of Europe and North America (Ciais et al., 2006) to tropical regions. The mean coefficient of correlation between NBP and GPP variations over the period 1901-2002 $\left(R^{2}=0.53 ; p<0.001\right)$ is greater than the one of NBP with TER $\left(R^{2}=0.28 ; p<0.001\right)$. The biome where NBP and GPP are best correlated is savanna south of the Equator $\left(R^{2}=0.63\right)$. The one where they are the least correlated is croplands in northern Africa $\left(R^{2}=0.41\right.$; see Table 2$)$. For rainforests distributed around the Equator, the correlation between NBP and GPP is lower than for savanna. This suggests a stronger decoupling in forests between TER and GPP, likely due to stem respiration and stem growth processes.

Third, the interannual variability of GPP and hence of the carbon balance, is driven by rainfall fluctuations rather than by temperature at the continental scale (Fig. 4). The correlation between GPP and rainfall $(P)$ during the interval 19012002 is positive and significant over $70 \%$ of the grid points. The dominant driving climate variable also varies between each biome (Table 3 ). The correlation between GPP and $P$ is the highest for savanna. About $77 \%$ and $42 \%$ of interannual
Table 2. ORCHIDEE model derived square of correlation coeffcient $\left(R^{2}\right)$ between GPP and NBP and TER and NBP for each biome.

\begin{tabular}{llrr}
\hline & & $\begin{array}{r}R^{2} \\
(\text { GPP-NBP) }\end{array}$ & $\begin{array}{r}R^{2} \\
(\text { TER-NBP) }\end{array}$ \\
\hline \multirow{3}{*}{ Northern Hemisphere } & Forest & 0.48 & 0.33 \\
& Savanna & 0.55 & 0.24 \\
& Croplands & 0.41 & 0.21 \\
& Forest & 0.48 & 0.29 \\
Southern Hemisphere & Savanna & 0.63 & 0.24 \\
& Croplands & 0.52 & 0.22 \\
\hline
\end{tabular}

variations of GPP in savanna is explained by precipitation, respectively in southern and northern savanna. In contrast, rainfall only weakly explains the interannual variability of GPP in forest (7\% in northern, and 6\% in southern forests), slightly less than temperature (9\% in northern and $19 \%$ in southern forest). Moreover, the slope of the GPP vs. $P$ regression is smaller for forest $\left(0.5-0.6 \mathrm{gC} \mathrm{m}^{-2} \mathrm{yr}^{-1} \mathrm{~mm}^{-1}\right)$ than for savanna $\left(0.9-1 \mathrm{gC} \mathrm{m}^{-2} \mathrm{yr}^{-1} \mathrm{~mm}^{-1}\right)$. This result may be related to the fact that, in the hydrology module of ORCHIDEE, forests can access deeper water sources than grasses. In addition, the different growth environments may contribute to the different response of GPP to temperature and rainfall. Forests are always located in areas with relatively abundant rainfall, whereas savannas are distributed in more arid environments, where vegetation growth is more frequently limited by soil moisture (Knapp et al., 2001).

Fourth, the dominant spatial pattern of interannual variability in GPP, TER, fire emissions and NBP over Africa is related to the El Niño mode of the global ENSO oscillation, with less GPP, more fires, and a coincident net carbon loss by ecosystems during El Niño episodes (Fig. 5) where a Principal Component Analysis has been applied to the ORCHIDEE output (ESRI, 1992). In this figure, the first Empirical Orthogonal Function mode (EOF), explaining $52 \%$ of the carbon balance variability, is nearly identical to the average NBP anomaly during an El Niño episode. At the continental scale, the impact of an El Niño episode is however not associated with a uniform change in rainfall/temperature patterns, but rather with regionally warmer and dryer conditions over Southern Africa from December to February and wetter conditions in the Great lakes region (see http://iri.columbia.edu/cgitest-bin/enso_map-req1.pl). A La Niña event manifests itself by a symmetrical pattern in anomalous rainfall (see also: http://iri.columbia.edu/climate/ ENSO/globalimpact/temp_precip/region_lanina.html). Over West Africa, the rainfall variability in Sudan and Sahel is also highly positively correlated with ENSO, but rainfall variability near the Guinean Coast is better predicted by the more local signal of SST anomalies in the Guinean gulf (Joly et 

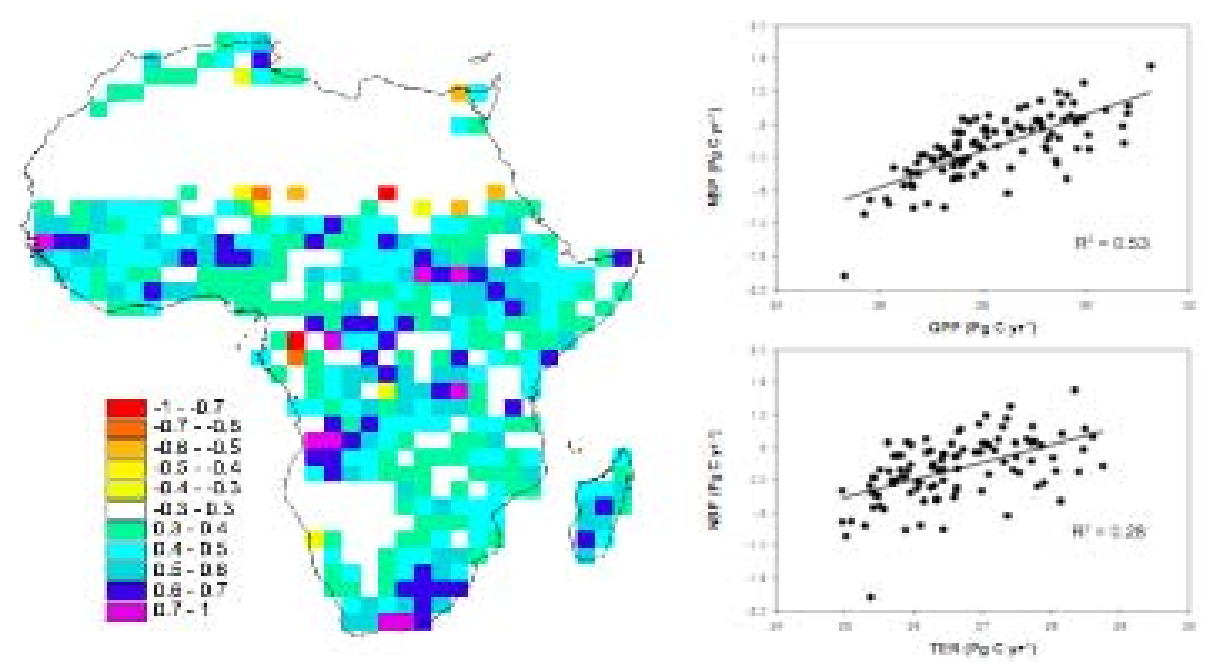

Fig. 3. Spatial distribution of the difference of explained interannual variance $\left(R^{2}\right)$ of GPP and TER on NBP. A blue color indicates that NBP variations are mostly driven by GPP variations. A red color indicates a dominant control of TER variations.

Table 3. Square of correlation coeffcient $\left(R^{2}\right)$ and slope $\left(\mathrm{gC} \mathrm{m}^{-2} \mathrm{yr}^{-1} \mathrm{~mm}^{-1}\right.$ or $\left.\mathrm{gC} \mathrm{m}^{-2} \mathrm{yr}^{-1 \circ} \mathrm{C}^{-1}\right)$ between GPP and precipitation $(P)$, GPP and temperature $(T), \mathrm{NBP}$ and precipitation $(P)$, and NBP and temperature $(T)$.

\begin{tabular}{lrrrrrrrrrr}
\hline & & \multicolumn{2}{c}{ GPP vs. $P$} & \multicolumn{2}{c}{ GPP vs. $T$} & \multicolumn{2}{c}{ NBP vs. $P$} & \multicolumn{2}{c}{ NBP vs. $T$} \\
\cline { 3 - 10 } & & $R^{2}$ & Slope & $R^{2}$ & Slope & $R^{2}$ & Slope & $R^{2}$ & Slope \\
\hline Northern & Forest & 0.07 & 0.5 & 0.09 & 174 & 0.06 & 0.1 & 0.08 & -28 \\
Hemisphere & Savannas & 0.77 & 1.0 & 0.09 & -79 & 0.50 & 0.3 & 0.07 & -24 \\
& Crop & 0.52 & 0.8 & 0.04 & -56 & 0.25 & 0.1 & 0.004 & -13 \\
Southern & Forest & 0.06 & 0.6 & 0.19 & 244 & 0.24 & 0.3 & 0.04 & -24 \\
Hemisphere & Savannas & 0.42 & 0.9 & 0.07 & -67 & 0.50 & 0.4 & 0.09 & -36 \\
& Crop & 0.45 & 0.8 & 0.01 & -30 & 0.35 & 0.3 & 0.04 & -19 \\
\hline
\end{tabular}

al., 2007). There has been a rather abundant literature on possible carry-over effects of soil moisture on climate in $\mathrm{Sa}$ hel, without yet a clear evidence for such a mechanism (Douville et al., 2007). Similarly, vegetation feedbacks on climate in the driest part of Sahel have been suggested (Los et al., 2006; Zeng et al., 1999). From the response of NBP to El Niño shown in Fig. 5, we expect forests in the inner-tropical band from the Congo basin to the Great Lakes region to store more carbon during El Niño episodes, while savannas are exposed to dryer conditions and show a reduced photosynthetic activity (see NDVI anomalies in Fig. 5), and thus a reduced GPP and NBP (Fig. 2). The net carbon balance anomalies of savannas are however not only driven by GPP, but also by fire disturbance as well (e.g. Williams et al., 2007), with wet years being committed to larger fire emissions during the next dry season (Barbosa et al., 1999; Balfour and Howison, 2001). In the fire module of ORCHIDEE, however, the role of fire emission $\left(R^{2}=0.15, P<0.001\right)$ in explain- ing the interannual variability of NBP is much lower than that of GPP $\left(R^{2}=0.53, P<0.001\right)$ or even TER $\left(R^{2}=0.28\right.$, $P<0.001$ ) (Fig. 1). For the magnitude in response to El Niño $\left(5 \mathrm{gC} \mathrm{m}^{-2} \mathrm{yr}^{-1}\right)$, fire anomaly is much lower than that of GPP $\left(50 \mathrm{gC} \mathrm{m}^{-2} \mathrm{yr}^{-1}\right)$ and TER $\left(20 \mathrm{gC} \mathrm{m}^{-2} \mathrm{yr}^{-1}\right)$. Finally, although ENSO seems to dominate, other climate modes might explain regional variations in African $\mathrm{C}$ fluxes. In particular heavy eastern Africa rainfalls were shown to correlate with the Indian Ocean Dipole mode (Saji et al., 2009).

A fifth result is that the African fire emissions in ORCHIDEE are only weakly sensitive to ENSO related climate variability, a feature also observed in satellite burned area records (Van der Werf et al., 2006). Fire emissions are linked to climate variability both directly via a bigger fire risk during the dry season, and indirectly via the controlling effects of climate on the growth of biomass during the former wet season, as a source of fuel. African fire emission proxy data have been analyzed by Chédin et al. (2008) from the 

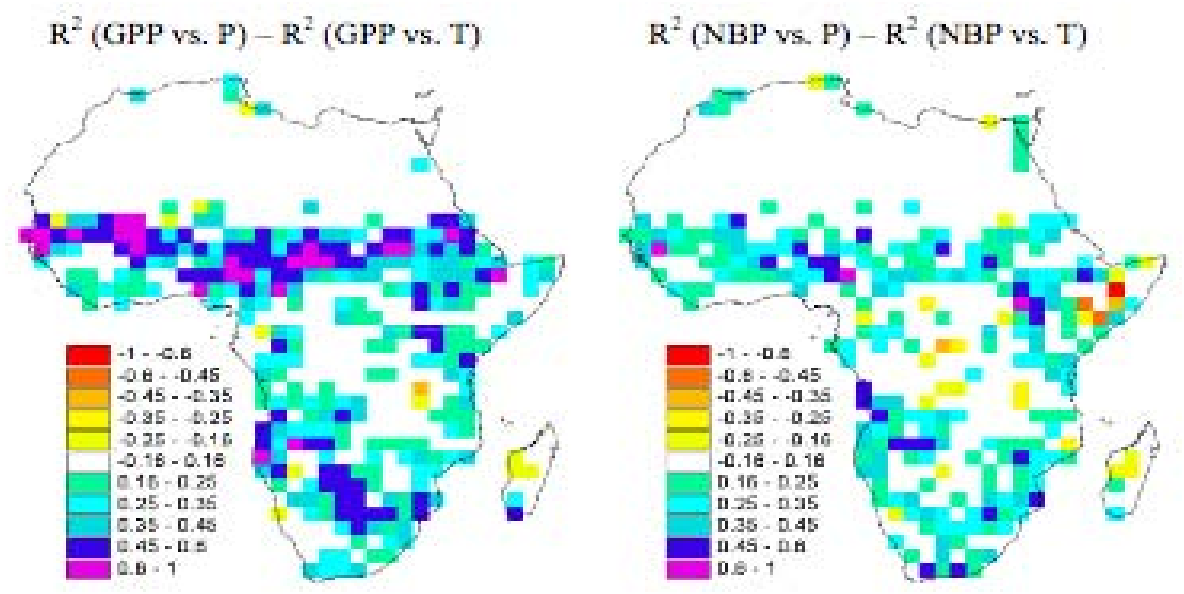

Fig. 4. Spatial distribution of the difference of explained interannual variance $\left(R^{2}\right)$ of precipitation $(P)$ and temperature $(T)$ on the GPP and NBP.

Table 4. Ratio of fire emissions (mainly in savannas) between El Niño and La Niña climate conditions. Comparison between satellite emission datasets and ORCHIDEE modeled fire emissions, as well as NPP and biomass, the two latter variables being taken as a proxy of the fuel available for burning. GFEDv2=van der Werf et al., 2006.

\begin{tabular}{lrrrr}
\hline Ratio El Niño to La Niña & $87 / 88$ & $87 / 89$ & $98 / 00$ & $98 / 99$ \\
\hline Satellite fire emissions & Chédin et al., 2008 & Chédin et al., 2008 & GFEDv2 & GFEDv2 \\
\hline Region & & & & \\
Total Africa & 1.1 & 1.0 & 1.0 & 1.1 \\
NH & 0.8 & 0.7 & 0.8 & 0.9 \\
SH & 1.2 & 1.1 & 1.3 & 1.4 \\
\hline Modeled fire emissions & & & & \\
\hline Total Africa & 1.04 & 1.07 & 0.82 & 0.84 \\
NH & 1.10 & 1.09 & 0.76 & 0.84 \\
SH & 0.97 & 1.05 & 0.90 & 0.84 \\
\hline Modeled NPP & & & & \\
\hline Total Africa & 0.89 & 0.86 & 0.97 & 1.01 \\
NH & 0.85 & 0.83 & 1.07 & 1.03 \\
SH & 0.94 & 0.89 & 0.88 & 0.99 \\
\hline Modeled biomass & & & & \\
\hline Total Africa & 0.89 & 0.85 & 0.95 & 1.09 \\
NH & 0.92 & 0.88 & 1.00 & 1.10 \\
SH & 0.83 & 0.82 & 0.86 & 1.07 \\
\hline
\end{tabular}

Diurnal Tropospheric Excess (DTE), a variable derived from the TOVS satellite observations over the period 1987-1991 (Chédin et al., 2003, 2005). We also analyzed the GFEDv2 biomass burning $\mathrm{C}$ emission dataset estimated from EOSTerra-MODIS burned area product (Giglio et al., 2006) prescribed to the CASA vegetation model over the period 1997 2004 (Van der Werf et al., 2006). Both burned-area and DTE datasets indicate consistently over their respective period of coverage that the El Niño to a La Niña ratio of fire emissions is only equal to 1.1 at the continental scale (Table 4), indicating no big change in fire emission between these two contrasted ENSO modes. This feature is well captured by ORCHIDEE (Table 4) over the whole period 1901-2002. Considering only the period 1987-2000, the modeled El Niño to a La Niña ratio of emissions varies between 0.82 and 1.07, also in correct agreement with the satellite datasets. 

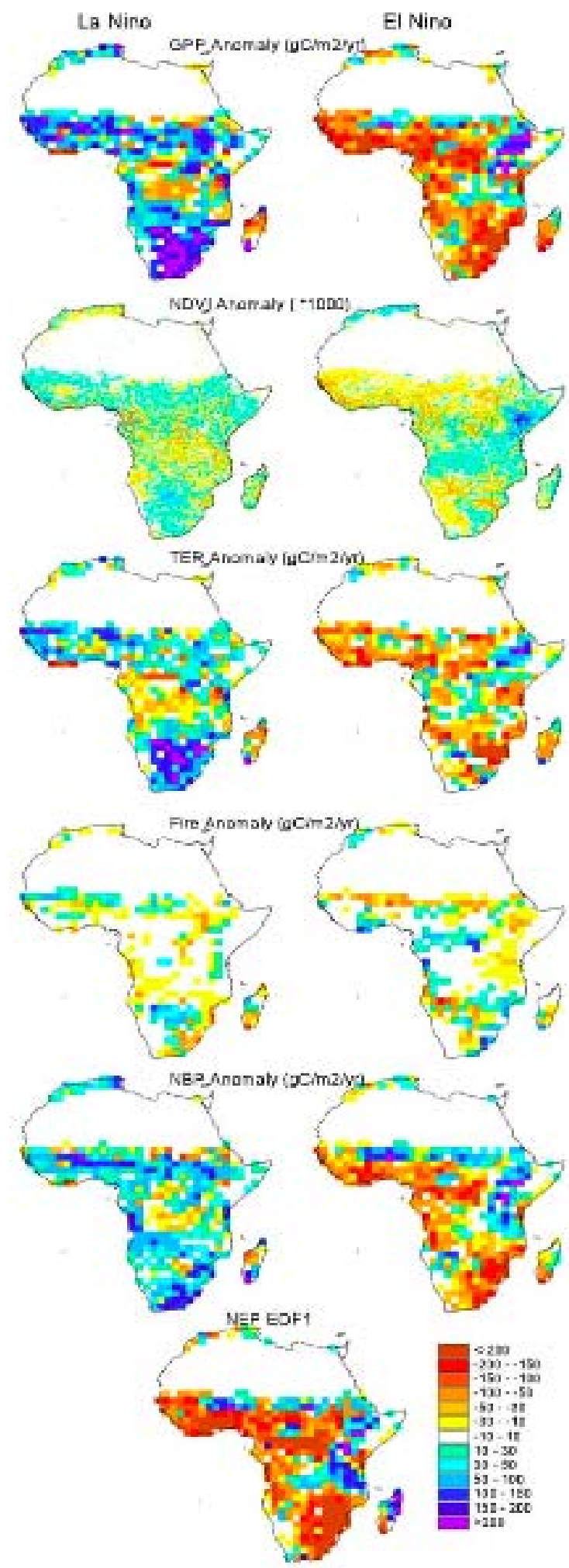

Fig. 5. Anomalies of GPP, NDVI, TER, Fire emission, and NBP during La Niña years (average of 1976 and 1989) and an El Niño year (average of 1983 and 1998). The bottom panel shows the pattern of the first (i.e. dominant) Empirical Orthogonal Function of the NBP variability, which resembles the El Niño typical anomaly.
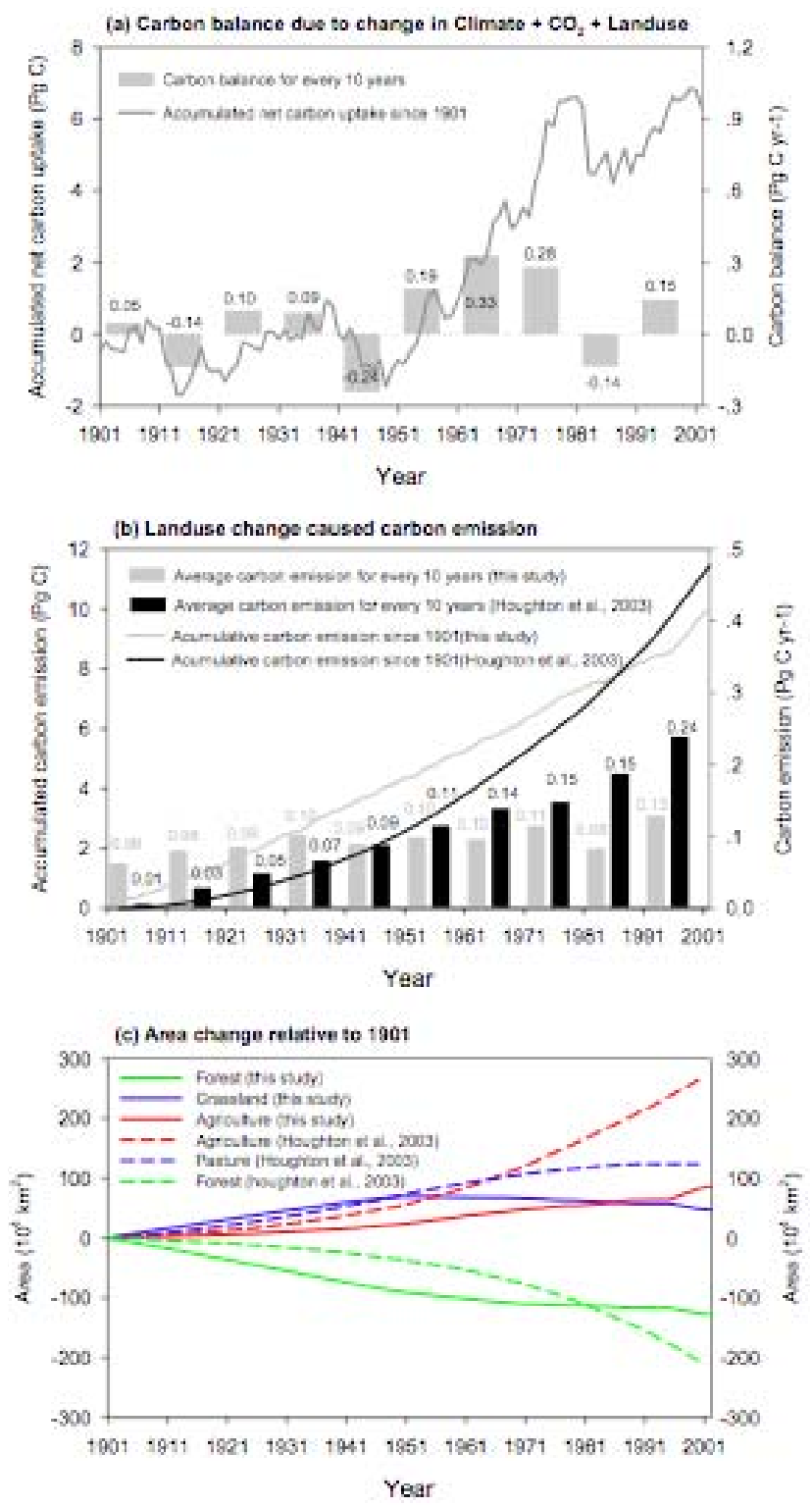

Fig. 6. ORCHIDEE modeled carbon emission due to land use change from 1901-2002.

The satellite data further indicate (Chédin et al., 2008) that El Niño to La Niña emission ratio are lower than unity in northern tropical Africa, and higher than unity in southern tropical Africa. This asymmetric response of fire emissions in each hemisphere to ENSO is shown by the DTE fire proxy for the ratio of the 1987 El Niño to the 1989 La Niña. It is also shown by the GFEDv2 burned-area derived emissions for the ratio of the 1997/1998 El Niño to the 1999 La Niña (Table 4). For savannas, Van der Werf et al. (2006) further pointed out that interannual variability in fire emissions is decoupled from the variability in burned area, and thus could be driven instead by the amount of fuel available, by different vegetation structure and by human-controlled fire regimes. 
To further test the hypothesis that a distinct El Niño to La Niña ratio of fire emissions in each hemisphere is driven by fuel load availability rather than by climate, we calculated in ORCHIDEE the corresponding ratios of NPP, and of standing biomass before the fire season. But no evidence for an asymmetric response of NPP and biomass to El Niño in each hemisphere was found (Table 4). This could reflect model shortcomings in capturing the interannual dynamics of biomass, more complex processes (lagged effects, nutrients), or regional decoupling between biomass available for fuel and actual fire emissions (human factors, landscape fragmentation, nature of combustions; see Archibald et al., 2009).

\section{Decadal terrestrial balance and trends}

Overall, we found that African NBP changed from a net carbon source of $0.14 \mathrm{CPg} \mathrm{yr}^{-1}$ in the 1980 s to a net carbon sink of $0.15 \mathrm{PgC} \mathrm{yr}^{-1}$ in 1990s. There are four main results arising from our set of simulations. The first result is that land use change during the last two decades implies a smaller source of $\mathrm{CO}_{2}$ to the atmosphere than expected from a global bookkeeping model using national land use area statistics (Houghton et al., 2003). The ORCHIDEE modeled LUC flux is a source of $0.08 \mathrm{PgC}^{-1}$ in the 1980s and of $0.13 \mathrm{Pg} \mathrm{C} \mathrm{yr}^{-1}$ in the 1990s. This LUC source is close to the estimate of Jain et al. (2005), based on the same land use area data but using a simpler carbon cycle model $\left(0.09 \mathrm{PgC} \mathrm{yr}^{-1}\right.$ in 1980s). Our estimate is only half of the Houghton et al. bookkeeping model (0.19 $\mathrm{Pg} \mathrm{C} \mathrm{yr}^{-1}$ in 1980s and $0.24 \mathrm{Pg} \mathrm{C} \mathrm{yr}^{-1}$ in 1990s). Over 2000-2005, the Houghton et al. model results give a LUC source of $0.24 \mathrm{Pg} \mathrm{C} \mathrm{yr}^{-1}$, stable compared to the 1990's estimate (Canadell et al., 2009).

A primary cause at the continental scale for a smaller LUC flux to the atmosphere in our simulation than in the bookkeeping model may be the very different rate of change in cropland area (Jain et al., 2005). The Ramankutty et al. (1999) dataset which we used, gives an African cropland area of $1.4 \times 10^{4} \mathrm{~km}^{2}$ in the 1990's with a strong decreasing trend, compared to an area of $5.2 \times 10^{4} \mathrm{~km}^{2}$ used by Houghton et al. (2003) with an increasing trend. Jain et al. (2005) found that $0.036 \mathrm{Pg} \mathrm{yr}^{-1}$ more carbon is emitted by land use change in the 1980 s when applying the cropland area of Houghton et al. (2003) instead of Ramankutty et al. (1999). The relatively small source contributed by land use changes in Africa as compared to other tropical forest regions reflects smaller deforestation rates before 2000. After 2000 however, forest clearing rates in Africa seem to have increased. In "hot-spot" regions of deforestation like Malaysia, Indonesia or in the Brazilian Amazon, most of forest suppression is driven by large clearings $>500 \mathrm{ha}(\mathrm{G}$. R. van der Werf, personal communication, 2008). Over these clearings are established palm oil plantations in Malaysia, Indonesia, Thailand (ECD, 2000; Stone 2007), and soybean fields fol- lowed by ranching in the Amazon (Morton et al., 2006). In Africa, most of the forests remain state-owned and despite widespread low-intensity logging in Cameroon, in the northern part of the Republic of Congo and in the western part of Gabon (Lepers et al., 2005; Laporte et al., 2007), there is no policy or strong population/economic pressure in Africa which favors large scale clearing for agriculture or plantation (Lambin et al., 2003), unlike in Asia and South-America. In particular, agro-industrial scale clearing is absent, unlike in South-East Asia and Latin America.

The difference of $0.14 \mathrm{Pg} \mathrm{C} \mathrm{yr}^{-1}$ between our LUC source and the estimate of Canadell et al. (2009) illustrates the large uncertainties in estimating changes in forest area, forest biomass, and release of $\mathrm{C}$ from cleared areas. Grainger (2008) reported that constructing reliable trends in tropical forest area is difficult, with evidence for decline still being unclear. For Africa, based upon different successive Forest Resources Areas census from FAO (1982, 1993, 2001), he reported a mean forest area ranging from 5.28 to $6.29 \times 10^{6} \mathrm{~km}^{2}$ in the 1990 's, and a forest area decline between the 1980's and the 1990's ranging from $0.41 \times 10^{6} \mathrm{~km}^{2}$ to $0.55 \times 10^{6} \mathrm{~km}^{2}$ over 25 years Using a sampling of highresolution satellite observations, Hansen et al. (2008) found a decline in Africa's humid forest biome of $5.4 \%$ of the global decline (with a standard error of $\pm 26 \%$ ) during 2000-2005, representing a loss of $0.014 \times 10^{6} \mathrm{~km}^{2}$ over 6 years. One can appreciate the large difference in area loss rate between this satellite based estimate and the census-based numbers above, some being due to different definitions of forest. Such discrepancies in cleared forest area, as well as in forest biomass estimates (see Houghton, 2005), translate into large differences in calculated LUC emissions.

Second, there is an upward trend of GPP and NBP between 1980 and 2002, which is widespread over the continent except for forested regions in Central Africa and around the Great Lakes. At the continental-scale, the trend of GPP is closely matching the trend in satellite observed NDVI (see Fig. 7 and Fig. 8). At the regional scale, our simulated trend in GPP is also consistent with an increased vegetation activity over Sahel reported by Eklhundh and Olsson (2003) and Olsson et al. (2005). This upward trend of GPP over savannas is parallel with a rise in precipitation (Trenberth et al., 2008, their Fig. 3.13), itself maybe associated with a polewards expansion of the Tropical belt (Seidel et al., 2008). At the continental-scale, the trend of GPP can be explained using our factorial simulations (Sect. 2) by the $\mathrm{CO}_{2}$ fertilization effect (70\%) ameliorated by the increase in $P$ $(44 \%)$. Other factors like temperature and solar radiation contributed only marginally to the continental trend of GPP (Fig. 7). In response only to temperature change, the total GPP even shows a statistically significant decreasing trend $\left(R^{2}=0.25, P<0.05\right)$ likely due to an increase in the transpiration to precipitation ratio. Excluding land use change, carbon sink for savanna is $0.05 \mathrm{Pg} \mathrm{Cyr}^{-1}$ while that of forest is about $0.3 \mathrm{Pg} \mathrm{C} \mathrm{yr}^{-1}$ in 1990s. In contrast to the drivers of 

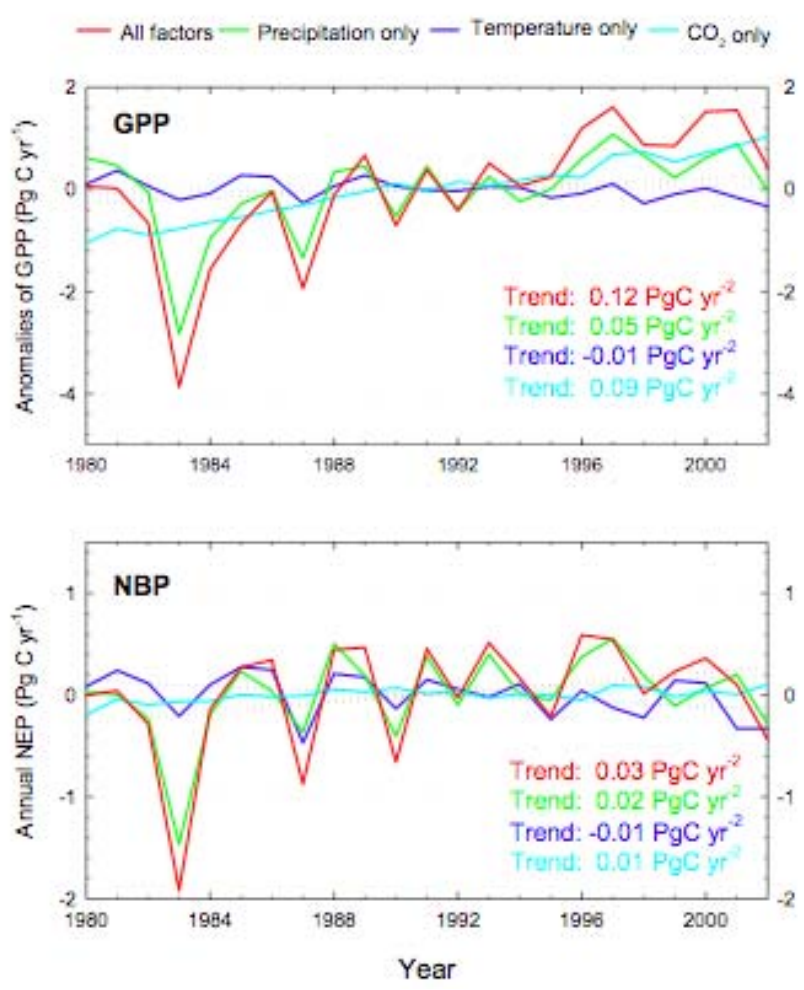

Fig. 7. Interannual changes and trends of GPP and NBP driven by different factors.

the GPP trend, the contribution of $\mathrm{CO}_{2}$ fertilization $(25 \%)$ to the trend of NBP is much less than that of precipitation (74\%). NBP is the difference between gross fluxes, whose driving forces partly compensate each other. The small extra quantity of carbon fixed from the atmosphere by the fertilization effect is systematically returned to the atmosphere by fires and by microbial decomposition, so that the NBP trend is less sensitive to the effect of rising $\mathrm{CO}_{2}$ than the GPP trend (Fig. 8).

Third, slow decadal-scale variations of GPP are followed by TER variations. This coupling between gross fluxes on decadal time scales (see Botta et al., 2002) also implies that the spatial patterns of GPP trends are parallel with similar patterns of TER trends, as shown by Fig. 8. This coupling of GPP and TER slow variations can also be seen in Fig. 1, superimposed on the interannual variability signal. In ORCHIDEE, the $\mathrm{CO}_{2}$ fertilization over forests between $10^{\circ} \mathrm{S}$ and $10^{\circ} \mathrm{N}$, and the effect of rising $P$ elsewhere over the savannas, explain the GPP and TER trends during the past 20 years. On the other hand, the NBP trend during that interval (as well as the NBP slow decadal variations during the past century) is driven by more subtle, second-order controlling variables, like the negative effect of regionally declining precipitation in Central Africa and the Great Lakes (Fig. 8).

Fourth, there is a increase in African river runoff since 1980 which is attributed to increasing rainfall, with a small additional contribution of decreasing forest area rather than to increasing $\mathrm{CO}_{2}$ in our simulations. At the continental scale, the modeled annual runoff due to the combined effects of climate, land use, and atmospheric $\mathrm{CO}_{2}$ reveals a significant positive trend of $1.24 \mathrm{~mm} \mathrm{yr}^{-2}\left(R^{2}=0.19, P<0.05\right)$ from 1980 to 2002 (Fig. 9). Such a dramatic increase in runoff is mainly due to increasing precipitation $\left(1.39 \mathrm{~mm} \mathrm{yr}^{-2}\right)$ and land use change $\left(0.09 \mathrm{~mm} \mathrm{yr}^{-2}\right)$. In contrast, rising atmospheric $\mathrm{CO}_{2}$ and temperature change caused a slight decrease in runoff by $-0.04 \mathrm{~mm} \mathrm{yr}^{-2}$ and $0.06 \mathrm{~mm} \mathrm{yr}^{-2}$, respectively. Such a decrease in runoff in response to rising atmospheric $\mathrm{CO}_{2}$ suggests that transpiration is not suppressed by higher $\mathrm{CO}_{2}$ levels, because the increased water use efficiency is offset by faster plant growth and more leaf area (Piao et al., 2007).

\section{Concluding remarks}

Another paper in this issue by Canadell et al. (2009) quantifies the African fossil fuel emission at $0.26 \mathrm{PgC} \mathrm{yr}^{-1}$ for 2000-2005. The present study finds a net terrestrial C sink of $0.15 \mathrm{PgC} \mathrm{yr}^{-1}$ for the $1990 \mathrm{~s}$, including LUC emissions of $0.13 \mathrm{PgC} / \mathrm{y}$, and a terrestrial C sink excluding LUC of $0.28 \mathrm{PgC} \mathrm{yr}^{-1}$. Thus Africa is unique among the world's large continents in having a terrestrial sink of similar magnitude (but opposite sign) to total emissions. Our estimate of the terrestrial carbon balance, however, does not include the impact of logging. The amount of harvested wood from African forests is of $0.125 \mathrm{PgC} \mathrm{yr}^{-1}$, with a high uncertainty (FAO, 2007). This flux will eventually return to the atmosphere in the future. Moreover, we found that that African ecosystems were a source of $0.14 \mathrm{PgC} \mathrm{yr}^{-1}$ in the $1980 \mathrm{~s}$, demonstrating that climate change can tip the African terrestrial carbon balance balance from sink to source.

If Africa is a net sink of atmospheric $\mathrm{CO}_{2}$ in our simulation, it is because photosynthesis has increased in excess of respiration and fire emissions during the last decades, increasing carbon sequestration. In savannas, we found that carbon accumulates in the soil (95\%). These ecosystems accounts for $11 \%$ of the natural sink over the African continent, excluding land use changes. Note however that this model result is not confirmed by field observations (E. Mougin, personal communication, 2008) over Sahelian savannas, where the observed soil C sink is very low. The Sudan savannas may have a very different carbon balance than the Sahel savannas, though.

In forest, carbon is mainly sequestered into biomass and accounts for another $89 \%$ of the natural sink at the continental scale. The forest sink is thus 7 times larger than the savanna sink. Note however that Africa was a carbon source during the 1980's, and that even during the 1990s, NBP is not always a carbon sink each year (Fig. 1). We expect the African forest carbon stocks to remain vulnerable in the coming decades. Africa has currently the smallest deforested area 


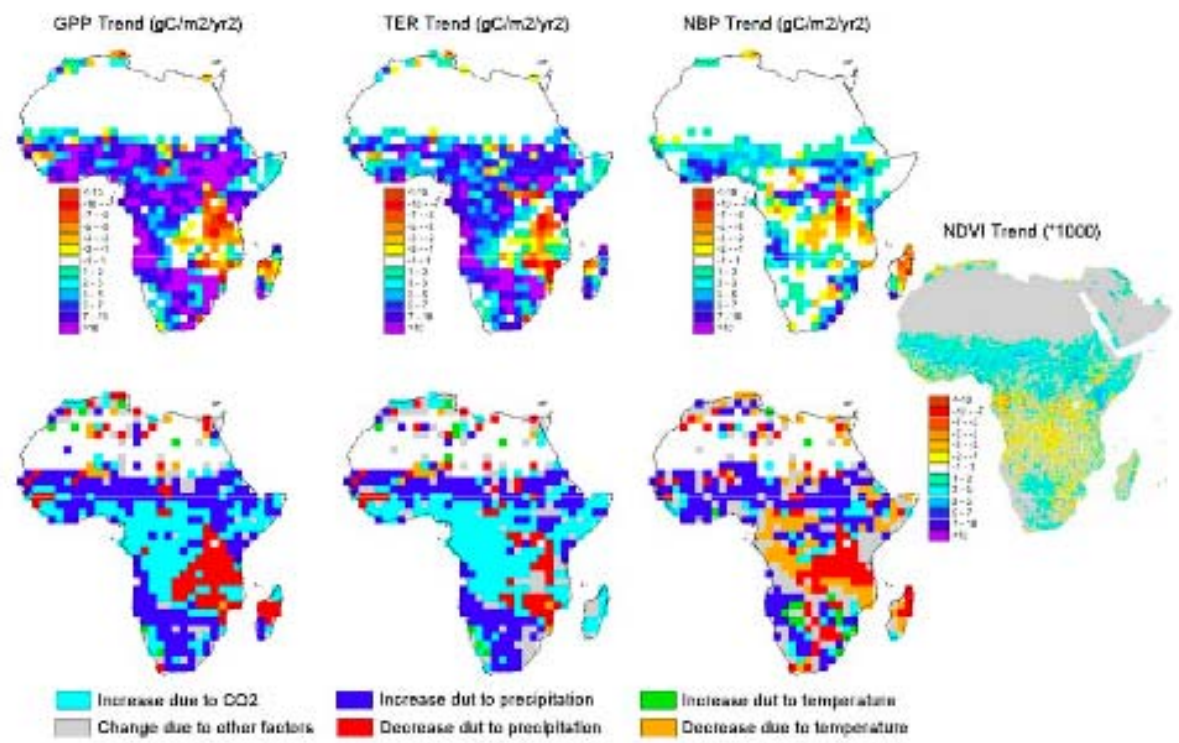

Fig. 8. Spatial distributions of modeled trends in annual GPP, TER and NBP s from 1980 to 2002 and of their main driving factor. In the bottom panels, the main driving factor among changing rainfall, $\mathrm{CO}_{2}$ and temperature for each grid point is calculated as the factor whose trend explains most of the trend in the simulation where all the factors are combined. The right hand panel compares the patterns of modelled trends with those of satellite NDVI trends.

of tropical regions (Achard et al., 2004), but shows higher forest clearing rate than e.g. South America (Achard et al., 2002; Canadell et al., 2009). This is partly linked to the establishment of plantations (50\% of deforested areas being converted to savanna and woodland, not agriculture). Further, there is a trend to intensified logging in Central Africa. The pristine African forests least affected by logging, are located in eastern Central Africa (Laporte et al., 2007), where we found that the recent regional drying trend has decreased GPP. This regional GPP decline is corroborated by satellite observation.

The next logical step will be to evaluate in details the model predictions. This can be done using forthcoming eddy covariance measurements (http://www.fluxnet. ornl.gov/fluxnet/networkname.cfm?networkid=36). Satellite measurements of soil moisture changes (Wagner et al., 2007) could also be used, with the benefits of existing long time series. But a better "observation operator" would be needed in ORCHIDEE to match with surface soil moisture observations from space, the current simple 2-buckets model hydrology being rather ill-adapted to arid and semi-arid regions. Productivity and phenology changes can be further evaluated by using remote sensing visible and infrared reflectance indexes (as briefly attempted here), as well as by compiling existing long time in situ series of NPP. The main structural development that is needed in ORCHIDEE is a better description of the savanna biome functioning, in particular a more realistic hydrology, fire module and phenology. One should account in this context for the co-existence and competition between trees and grasses (Botta et al., 2002) in modelling

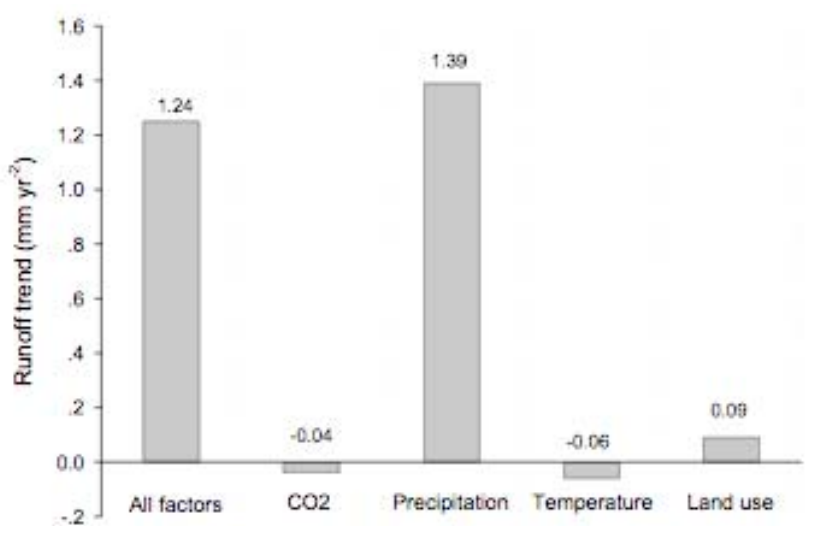

Fig. 9. Trend in African runoff driven by different environmental factors.

savannas carbon stocks and fluxes. Our simulations show that ecosystem respiration variations are systematically tailing out with those of photosynthesis, and that $2 / 3$ of the respiration anomalies are caused by autotrophic respiration. In that context, the possible acclimation of autotrophic respiration to high-temperature and drought (Maseyk et al., 2008) should be accounted in new model parameterizations.

The main model input dataset that are needed are a more reliable crop present and historical land-cover dataset for Africa, and more generally, information on the human land use pressure, including grazing and logging trends. Regarding climate forcing data, a monthly time step for precipitation 
as in the CRU dataset (that we further interpolated to hourly data with a weather generator), is clearly a big source of error. In dry regions, herbaceous vegetation is composed of annual plants that can grow immediately after rain. The phenology of this vegetation type will only be captured in models with a more realistic daily rainfall forcing data.

Acknowledgements. We are very grateful to F. Chevallier and to E. Mougin for their very useful comments on the manuscript. This study was supported by the EC funded projects CARBOEUROPE IP (GOCE-CT-2003-505572). S. L. Piao was supported by the Foundation for the Author of National Excellent Doctoral Dissertation of PR China (FANEDD-200737).

Edited by: J. Leifeld

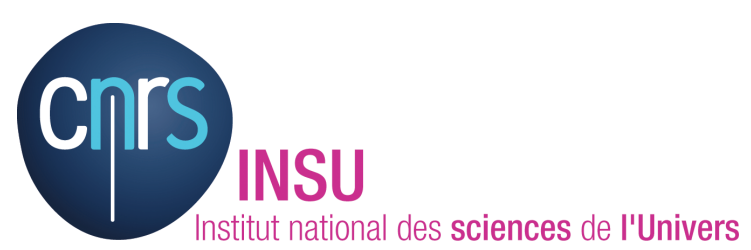

The publication of this article is financed by CNRS-INSU.

\section{References}

Abbadie, L., Gignoux, J., Le Roux, X., and Lepage, M.: Lamto: structure, functioning and dynamics of a savanna ecosystem, Springer-Verlag, New York, Ecological studies 179, 415 pp., 2006.

Ali, A. and Lebel, T.: The sahelian standardized rainfall index revisited, Int. J. Climatol, 19, 1705-1714, 2009.

Achard, F., Eva, H. D., Stibig, H. J., Mayaux, P., Gallego, J., Richards, T., and Malingreau, J. P.: Determination of Deforestation Rates of the World's Humid Tropical Forests, Science, 297, 999-1002, 2002.

Achard, F., Eva, H. D., Mayaux, P., Stibig, H. J., and Belward, A.: Improved estimates of net carbon emissions from land cover change in the tropics for the 1990s, Global Biogeochem. Cy., 18, GB2008, doi:10.1029/2003GB002142, 2004.

Archibald, S., Roy, D. P., Van Wilgen B., and Scholes R. J.: What limits fire? An examination of drivers of burnt area in Southern Africa, Glob. Change Biol., 15(3), 613-630, 2009.

Balfour D. A. and Howison, O. E.: Saptial and temporal variation in a mesic savanna fire regime: responses to variation in annual rainfall, Afr. J. Range Forage Sci., 19, 43-52, 2001.

Barbosa, P. M., Stroppiana, D., Gregoire, J. M., and Pereira, J. M. C.: An assessment of vegetation fire in Africa (19811991): Burned areas, burned biomass, and atmospheric emissions, Global Biogeo. Cycles, 13(4), 933-950, 1999.

Botta, A., Ramankutty, N., and Foley, J. A.: Long-term variations of climate and carbon fluxes over the Amazon Basin, Geophys. Res. Lett., 29, 331-334, doi:10.1029/2001GL013607, 2002.

Brown, S. and Gaston, G.: Tropical Africa: Land Use, Biomass, and Carbon Estimates for 1980. (NDP-055) Carbon Dioxide Information and Analysis Center, Oak Ridge National Laboratory, Oak Ridge, TN, 1996.
Canadell, J. G., Raupach, M. R., and Houghton, R. A.: Anthropogenic $\mathrm{CO}_{2}$ emissions in Africa, Biogeosciences, 6, 463-468, 2009 ,

http://www.biogeosciences.net/6/463/2009/.

Chédin, A., Serrar, S., Hollingsworth, A., Armante, R., and Scott, N. A.: Detecting annual and seasonal variations of $\mathrm{CO}_{2}, \mathrm{CO}$, $\mathrm{N}_{2} \mathrm{O}$ from a multi-year collocated satellite-radiosonde dataset using the new rapid radiance reconstruction network (3R-N) model, J. Quant. Spectrosc. Ra. Transfer, 77, 285-299, 2003.

Chédin, A., Serrar, S., Scott, N. A., Pierangelo, C., and Ciais, P.: Impact of tropical biomass burning emissions on the diurnal cycle of upper tropospheric $\mathrm{CO}_{2}$ retrieved from NOAA 10 satellite observations, J. Geophys. Res., 110D11, D11309, doi:10.1029/2004JD005540, 2005.

Chédin, A., Scott, N. A., Armante, R., Pierangelo, C., Crevoisier, C., Fossé, O., and Ciais, Ph.: A quantitative link between $\mathrm{CO} 2$ emissions from tropical vegetation fires and the daily tropospheric excess (DTE) of $\mathrm{CO}_{2}$ seen by NOAA-10 (1987-1991), J. Geophys. Res., 113(D5), D05302, doi:10.1029/2007JD008576, 2008.

Chevallier, F., Viovy, N., Reichstein M., and Ciais P.: On the assignment of prior errors in Bayesian inversions of $\mathrm{CO}_{2}$ fluxes, Geophys. Res. Lett., 33, L13802, doi:10.1029/2006GL026496, 2006.

Ciais, P., Reichstein, M., Viovy, N., Granier, A., Ogee, J., Allard, V., Aubinet, M., Buchmann, N., Bernhofer, C., Carrara, A., Chevallier, F., De Noblet, N., Friend, A. D., Friedlingstein, P., Grunwald, T., Heinesch, B., Keronen, P., Knohl, A., Krinner, G., Loustau, D., Manca, G., Matteucci, G., Miglietta, F., Ourcival, J. M., Papale, D., Pilegaard, K., Rambal, S., Seufert, G. J., Soussana, F., Sanz, M. J., Schulze, E. D., Vesala, T., and Valentini, R.: Europe-wide reduction in primary productivity caused by the heat and drought in 2003, Nature, 437, 529-533, 2005.

Ciais, P., Piao, S. L., Viovy, N., Roedenbeck, C., Peylin, P., and Baker, D.:Top-down and bottom-up carbon budgets of North America, Europe and Asia, Eos Trans. AGU, 87(52), Fall Meet. Suppl., Abstract B42B-01, 2006.

Collatz, G. J., Ribas-Carbo, M., and Berry, J. A.: Coupled photosynthesis-stomatal conductance model for leaves of $\mathrm{C}_{4}$ plants, Aust. J. Plant Physiol., 19, 519-538, 1992.

Demarty, J., Chevallier, F., Friend, A. D., Viovy, N., Piao, S. L., and Ciais, P.: Assimilation of global MODIS leaf area index retrievals within a terrestrial biosphere model, Geophys. Res. Lett., 34, L15402, doi:10.1029/2007GL030014, 2007.

De Rouw, A.: Improving yields and reducing risks in pearl millet farming in the African Sahel, Agric. Syst., 81, 73-93, 2004.

Douville, H., Conil, S., Tyteca, S., and Voldoire, A.: Soil moisture memory and West African monsoon predictability: artefact or reality? Clim. Dynam., 28, 723-742, 2007.

Ducoudré, N. I., Laval, K., and Perrier, A.: SECHIBA, a new set of parameterizations of the hydrologic exchanges at the landatmosphere interface within the LMD atmospheric general circulation model, J. Climate, 6, 248-273, 1993.

ECD (State Environmental Conservation Department): Environmental Impact Assessment, Guidelines for Oil Palm Plantations development, Tech. Report 2, 2000.

Eklundh, L. and Olsson, L.: Vegetation index trends for the African Sahel 1982-1999, Geophys. Res. Lett., 30, 1430, doi:10.1029/2002GL016772, 2003. 
ESRI: Arc/Info User's Manual. Environmental Systems Research Institute, Redlands, California, USA, 1992.

Farquhar, G. D., Caemmerer, S., and Berry, J. A.: A biochemical model of photosynhetic $\mathrm{CO}_{2}$ assimilation in leaves of $\mathrm{C}_{3}$ species, Planta, 149, 78-90, 1980.

Food and Agriculture Organization of the United Nations: Tropical Forest Resources, Forestry Paper No 30 (United Nations Food and Agriculture Organization, Rome), 1982.

Food and Agriculture Organization of the United Nations: Forest Resources Assessment: Tropical Countries, Forestry Paper No 112 (United Nations Food and Agriculture Organization, Rome), 1993.

Food and Agriculture Organization of the United Nations: Global Forest Resources Assessment 2000, Forestry Paper No 140 (United Nations Food and Agriculture Organization, Rome), 2001.

Food and Agriculture Organization of the United Nations (FAO): State of the World's Forests 2007, 144 pp., 2007.

Giglio, L., van der Werf, G. R., Randerson, J. T., Collatz, G. J., and Kasibhatla, P.: Global estimation of burned area using MODIS active fire observations, Atmos. Chem. Phys., 6, 957-974, 2006, http://www.atmos-chem-phys.net/6/957/2006/.

Goldewijk, K. K.: Estimating global land use change over the past 300 years: The HYDE Database, Global Biogeochem. Cy., 15, 417-433, 2001.

Grace, J., San-José, J., Meir, P., Miranda, H. S., and Montes, R. A.: Productivity and carbon fluxes of tropical savannas, J. Biogeogr., 33, 387-400, 2006.

Grainger, A.: Difficulties in tracking the long-term global trend in tropical forest area, Proceedings of the National Academy of Sciences of the United States of America, 105(2), 818-823, 2008.

Haberl, H., Erb, K. H., Krausmann, F., Gaube, V., Bondeau, A., Plutzar, C., Gingrich, S., Lucht, W., and Fischer-Kowalski, M.: Quantifying and mapping the human appropriation of net primary production in earth's terrestrial ecosystems, P. Natl. Acad. Sci. USA, 104, 12942-12945, 2007.

Hansen, M. C., Stehman, S. V., Potapov, P. V., Loveland, T. R., Townshend, J. R. G., DeFries, R. S., Pittman, K. W., Arunarwati, B., Stolle, F., Steininger, M. K., Carroll, M., and DiMiceli, C.: Humid tropical forest clearing from 2000 to 2005 quantified by using multitemporal and multiresolution remotely sensed data, $\mathrm{P}$. Natl. Acad. Sci. USA, 105, 9439-9444, 2008.

Hiernaux, P. H. Y., Mougin, E., Diarra, L., Soumaguel, N., Lavenu, F., and Tracol, Y.: Sahelian rangeland response to changes in rainfall over two decades in the Gourma region, Mali, J. Hydrol., 375, 114-127, 2009.

Houghton, R. A.: Revised estimates of the annual net flux of carbon to the atmosphere from changes in land use and land management 1850-2000, Tellus B, 55, 378-390, 2003.

Houghton R. A.: Aboveground forest biomass and the global carbon balance, Glob. Change Biol., 11, 945-958, 2005.

Ingram, K. T., Roncoli, M. C., and Kirshen, P. H.: Opportunities and constraints for farmers of West Africa to use seasonal precipitation forecasts with Burkina Faso as a case study, Agric. Syst., 74, 331-349, 2002.

Jain, A. K. and Yang, X.: Modeling the Effects of Two Different Land Cover Change Data Sets on the Carbon Stocks of Plants and Soils in Concert With $\mathrm{CO}_{2}$ and Climate Change, Global Biogeochem. Cy., 19, GB2015, doi:10.1029/2004GB002349, 2005.
Joly, M., Voldoire, A., Douville, H., Terray, P., and Royer, J. F.: African monsoon teleconnection with tropical SSTs: validation and evolution in a set of IPCC4 simulations, Clim. Dynam., 29, 1-20, 2007.

Knapp, A. K. and Smith, M. D.: Variation among biomes in temporal dynamics of aboveground primary production, Science 291: 481- 484, 2001.

Koch, G. W., Vitousek, P. M., Steffen, W. L., and Walker, B. H.: Terrestrial transects for global change research, Vegetatio, 121, 53-65, 1995.

Krinner, G., Viovy, N., de Noblet-Ducoudre, N., Ogee, J., Polcher, J., Friedlingstein, P., Ciais, P., Sitch, S., and Prentice. I. C.: A dynamic global vegetation model for studies of the coupled atmosphere-biosphere system, Global Biogeochem. Cy., 19, GB1015, doi:10.1029/2003GB002199, 2005.

Lambin, E. F., Geist, H. J., and Lepers, E.: Dynamics of land-use and land-cover change in Tropical Regions, Annu. Rev. Environ. Res., 28, 205-241, 2003.

Laporte, N. T., Stabach, J. A., Grosch, R., Lin, T. S., and Goetz, S. J.: Expansion of Industrial Logging in Central Africa, Science, 316, p. 1451, 2007.

Lepers, E., Lambin, E. F., Janetos, A. C., DeFries, R., Achard, F., Ramankutty, N., and Scholes R. J.: A synthesis of information on rapid land-cover change for the period 1981-2000, BioScience, 55, 115-124, 2005.

Lieth, H. and Wietaker R. H.: Primary Productivity of the Biosphere, Springer Verlag, Berlin, 1975.

Los, S. O., Weedon, G. P., North, P. R. J., Kaduk, J. D., Taylor, C. M., and Cox, P. M.: An observation-based estimate of the strength of rainfall-vegetation interactions in the Sahel, Geophys. Res. Lett., 33 L16402, doi:10.1029/2006GL027065, 2006.

Loveland, T. R., Reed, B. C., Brown, J. F., Ohlen, D. O., Zhu, Z., Yang, L., and Merchant, J. W.: Development of a global land cover characteristics database and IGBP DISCover from $1 \mathrm{~km}$ AVHRR data, Int. J. Remote Sens., 21, 1303-1330, 2000.

Maseyk, K., Grunzweig, J. M., Rotenberg, E., and Yakir, D.: Respiration acclimation contributes to high carbon use efficiency in a seasonally dry pine forest, Glob. Change Biol., 7, 1553-1557, 2008.

McNaughton, S., Oesterheld, M., Franck, D., and Williams, K.: Ecosystem level patterns of primary productivity and herbivory in terrestrial habitats, Nature, 341, 142-144, 1989.

Menaut, J. C., Barbault, R., Lavelle, P., and Lepage, M.: African savannas: Biological systems of humification and mineralization, in: Ecology and management of the Worlds' savannas, edited by: Tothill, J. C. and Mott, J. J., Australian Academy of Science, Canberra, 1985.

Mitchell, T. D. and Jones, P. D.: An improved method of constructing a database of monthly climate observations and associated high-resolution grids, Int. J. Climatol., 25, 693-712, 2005.

Mitchell, T. D., Carter, T. R., Jones, P. D., Hulme, M., and New, M.: A comprehensive set of high-resolution grids of monthly climate for Europe and the globe: the observed record (19012000) and 16 scenarios (2001-2100), Tyndall Centre Working Paper 55, 2004.

Morton, D. C., DeFries, R. S., Shimabukuro, Y. E., Anderson, L. O., Arai, E., Espirito-Santo, F. D., Freitas, R., and Morisette, J.: Cropland expansion changes deforestation dynamics in the southern Brazilian Amazon, P. Natl. Acad. Sci. 
USA, 103, 14637-14641, 2006.

Olsson, L., Eklundh, L., and Ardö, J.: A recent greening of the Sahel, trends, patterns and potential causes, J. Arid Environ., 63, 556-566, 2005.

Parton, W., Stewart, J., and Cole, C.: Dynamics of C, N, P, and S in grassland soil: A model, Biogeochemistry, 5, 109-131, 1988.

Piao, S. L., Ciais, P., Friedlingstein, P., Peylin, P., Reichstein, M., Luyssaert, S., Margolis, H., Fang, J. Y., Barr, A., Chen, A. P., Grelle, A., Hollinger, D. Y., Laurila, T., Lindroth, A., Richardson, A. D., and Vesala, T.: Net carbon dioxide losses of northern ecosystems in response to autumn warming, Nature, 451, 49-52, 2008.

Piao, S. L., Friedlingstein, P., Ciais, P., de Noblet-Ducoudre, N., Labat, D., and Zaehle, S.: Changes in climate and land use have a larger direct impact than rising $\mathrm{CO}_{2}$ on global river runoff trends, P. Natl. Acad. Sci. USA, 104, 15242-15247, 2007.

Piao, S. L., Friedlingstein, P., Ciais, P., Zhou, L. M., and Chen, A. P.: Effect of climate and $\mathrm{CO}_{2}$ changes on the greening of the Northern Hemisphere over the past two decades, Geophys. Res. Lett., 33, L23402, doi:10.1029/2006GL028205, 2006.

Rayner, P. J., Scholze, M., and Knorr, W.: Two decades of terrestrial carbon fluxes from a carbon cycle data assimilation system(CCDAS), Global Biogeochem. Cy., 19, GB2026, doi:10.1029/2004GB002254, 2005.

Ramankutty, N. and Foley, J. A.: Estimating historical changes in global land cover: Croplands from 1700 to 1992, Global Biogeochem. Cy., 13, 997-1027, 1999.

Saji, N. H., Goswami, B. N., Vinayachandran, P. N., and Yamagata T.: A dipole mode in the tropical Indian Ocean, Nature, 401(6751), 360-363, 1999.

Scholes, R. J. and Hall, D.: The carbon budget of tropical savannas, woodlands and grasslands, in: Global Change: effects on coniferous forest and grasslands SCOPE, edited by: Breymeyer, A. I., Hall, D., Mellilo, J. M., and Agrn, G. I., John Wiley, New York, 69-100, 1996.

Seidel, D. J., Fu, Q., Randell, W. J., and Reichler, T. J.: Widening of the tropical belt in a changing climate, Nature-Geosci., 1, 21-24, 2008.

Sitch, S., Huntingford, C., Gedney, N., Levy, P., Lomas, M., Piao, S. L., Betts, R., Ciais, P., Cox, P., Friedlingstein, P., Jones, C. D., Prentice, I. C., and Woodward, F. I.: Evaluation of the terrestrial carbon cycle, future plant geography and climate-carbon cycle feedbacks using 5 Dynamic Global Vegetation Models (DGVMs), Global Change Biol., 14, 1-25, 2008.
Stone, R.: Can oilpalm plantations come clean?, Science, 317, p. 1491, 2007.

Sultan B., Baron, C., Dingkuhn, M., Saar, B., and Janicot, S.: Agricultural impacts of large-scale variability of the West African monsoon, Agr. Forest Meteorol., 128, 93-110, 2005.

Thonicke, K., Venevsky, S., Sitch, S., and Cramer, W.: The role of fire disturbance for global vegetation dynamics: Coupling fire into a Dynamic Global Vegetation Model, Global Ecol. Biogeogr., 10, 661-677, 2001.

Trenberth, K. E., Jones, P. D., Ambenje, P., Bojariu, R., Easterling, D., Klein Tank, A., Parker, D., Rahimzadeh, F., Renwick, J. A., Rusticucci, M., Soden, B., and Zhai, P.: Observations: Surface and Atmospheric Climate Change, in: Climate Change 2007: The Physical Science Basis. Contribution of Working Group I to the Fourth Assessment Report of the Intergovernmental Panel on Climate Change, edited by: Solomon, S., Qin, D., Manning, M., Chen, Z., Marquis, M., Averyt, K. B., Tignor, M., and Miller, H. L., Cambridge University Press, Cambridge, United Kingdom and New York, NY, USA, 2008.

van der Werf, G. R., Randerson, J. T., Giglio, L., Collatz, G. J., Kasibhatla, P. S., and Arellano Jr., A. F.: Interannual variability in global biomass burning emissions from 1997 to 2004, Atmos. Chem. Phys., 6, 3423-3441, 2006, http://www.atmos-chem-phys.net/6/3423/2006/.

Wagner, W., Naeimi, V., Scipal, K., de Jeu, R., and MartínezFernández, J.: Soil moisture from operational meteorological satellites, J. Hydrogeo., 15, 121-131, doi:10.1007/s10040-0060104-6, 2007.

Weber, U., Jung, M., Reichstein, M., Beer, C., Braakhekke, M. C., Lehsten, V., Ghent, D., Kaduk, J., Viovy, N., Ciais, P., Gobron, N., and Rödenbeck, C.: The interannual variability of Africa's ecosystem productivity: a multi-model analysis, Biogeosciences, 6, 285-295, 2009, http://www.biogeosciences.net/6/285/2009/.

Williams, C. A., Hanan, N. P., Neff, J. C., Scholes, R. J., Berry, J. A., Denning, A. S., and Baker, D. F.: Africa and global carbon cycle, Carbon Balance and Manag., 2(3), 1-13, doi:10.1186/1750-0680-2-3, 2007.

Zeng, N., Neelin, J.D., Lau, K.M. and Tucker, C.J.: Enhancement of interdecadal climate variability in the Sahel by vegetation interaction, Science, 286, 1537-1540, 1999.

Zobler, L.: A world soil file for global climate modeling. NASA TM-87802. National Aeronautics and Space Administration, Washington DC, 1986. 